\title{
VARIATION OF BIOACTIVE COMPOUNDS CONTENT IN FERMENTED CABBAGE: INFLUENCE OF FERMENTATION TEMPERATURE
}

\author{
PROMENA SADRŽAJA BIOAKTIVNIH JEDINJENJA U TOKU \\ FERMENTACIJE KUPUSA NA RAZLIČITIM TEMPERATURAMA
}

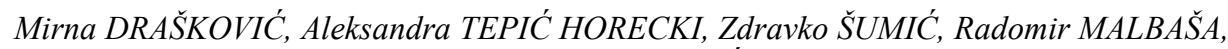 \\ Jasmina VITAS, Branimir PAVLIĆ, Anita VAKULA \\ Faculty of Technology, 21000 Novi Sad, Bulevar cara Lazara 1, Serbia \\ e-mail: anitavakula@uns.ac.rs
}

\begin{abstract}
The aim of this study was to analyze the effect of different fermentation temperature on bioactive compounds content of cabbage heads (Brassica oleracea var. capitata). Fermentation process was carried out at the temperature intervals $16-18{ }^{\circ} \mathrm{C}, 18-20{ }^{\circ} \mathrm{C}$ and 20-22 ${ }^{\circ} \mathrm{C}$ for 40 days. Dry weight, soluble dry weight, $\mathrm{pH}$ value, water activity, salt and sugar concentration, total acidity, penetration force, total color change, total phenolic compounds and organic acidswere investigated as the most important quality parameters. The highest content of total phenol compounds, as well as the highest contents of oxalic and acetic acidswas obtained in cabbage and brine sample fermented at $16-18{ }^{\circ} \mathrm{C}$. The highest content of lactic acid in the cabbage sample fermented at $20-22{ }^{\circ} \mathrm{C}$ was obtained. In the case of brine samples, the highest contents of oxalic and lactic acids in samples fermented at $16-18{ }^{\circ} \mathrm{C}$ were observed, while the highest content of acetic acid in the sample fermented at 20-22 ${ }^{\circ} \mathrm{C}$ was obtained. Formic acid in cabbage and brine samples only in samples fermented at $20-22{ }^{\circ} \mathrm{C}$ was detected.
\end{abstract}

Key words:cabbage, bioactive compounds, biologicalfermentation, fermentation temperature.

\section{REZIME}

Cilj ovog rada bio je analiziranje uticaja različitih temperatura fermentacije na sadržaj bioaktivnih jedinjenja kupusa (Brassica oleracea var.capitata) u glavicama. Fermentacija kupusa odvijala se u poljoprivrednom gazdinstvu na temperaturama $16-18^{\circ} \mathrm{C}, 18-$ $20^{\circ} \mathrm{C}$ i $20-22^{\circ} \mathrm{C}$ u trajanju od 40 dana. Uzorak kupusa i rasola uzet je za svaki ispitivani interval temperatura. Sadržaj suve materije $i$ rastvorljive suve materije, $p H$ vrednost, aktivnost vode, ukupna koncentracija soli i šećera, ukupan sadržaj kiselina, sila presecanja, ukupna promena boje, sadržaj fenolnih jedinjenja i sadržaj organskih kiselina ispitivani su u cilju praćenja procesa fermentacije. Najveći sadržaj fenolnih jedinjenja zabeležen je u uzorku kupusa i uzorku rasola fermentisanom na temperaturi 16-18 ${ }^{\circ} \mathrm{C}$. Takođe, najveći sadržaj oksalne i sirćetne kiseline zabeležen je u uzorku kupusa fermentisanom na temperaturi16-18 ${ }^{\circ} \mathrm{C}$, dok je najveći sadržaj mlečne kiseline zabeležen u uzorku kupusa fermentisanom na $20-22^{\circ} \mathrm{C}$. U slučaju ispitivanih uzoraka rasola, najveći sadržaj oksalne $i$ mlečne kiseline zabeležen je u uzorku fermentisanom na temperaturi $16-18{ }^{\circ} \mathrm{C}$, dok je najveći sadržaj sirćetne kiseline zabeležen u uzorku fermentisanom na temperaturi $20-22^{\circ} \mathrm{C}$. Mravlja kiselina zabeležena je samo u uzorku kupusa i rasola fermentisanom na temperaturi $20-22^{\circ} \mathrm{C}$.

Ključne reči: kupus, bioaktivne materije, biološka fermentacija, temperatura fermentacije.

\section{INTRODUCTION}

Serbian households traditionally made biologically fermented cabbage sliced into stripes or as whole heads. Cabbage (Brassica oleraceavar. capitata)is a widespread vegetable cropand it is very important for both health and economic reasons. This nutritionally valuable foodstuff could be consumed fresh, or as a coleslawand as abiologically fermented cabbage (Harbaum-Piayda et al., 2016). Biological fermentation is the most convenient way of cabbage preservation in terms of usage out of the season. The best domestic varieties, suitable for fermentation, are futoški prevalent in Vojvodina, and srpski melez, in Central Serbia (Niketić-Aleksić, 1988). In addition to these varieties, cabbage hybrids are also widely cultivated due to heads uniformity, better yield and good storage possibilities. Cabbage hybrid bravo has a good yieldand it is widely consumed in the form of fresh and fermented cabbage. Growing season of this hybrids approximately 90-95 days with recommended harvest time in the late fall. The outer leaves are bluish green, heads are round and tightly packed with mass between 2 and $3 \mathrm{~kg}$ per cabbage head (Cvetković, 2014).
During cabbage fermentation lactic acid is produced from sugar under the influence of microorganism activity. Afermented productsare characterized with an appealing aroma, flavor, texture, nutritional enrichmentand health promotion (Jevšnik et al., 2009; Terefe, 2016). During spontaneous fermentation microorganisms are growing and reproducingunder the influence of external factors (Batt, 2016). The manufacture of fermented cabbage heads depends on the metabolism and successive growth of lactic-acid bacteria, naturally present in a raw material (Hutkins, 2006). The metabolism of lactic-acid bacteria is well reported in the literature (Kumar and Pranay, 2010; Gänzle, 2015), as well as fermentation process of the whole cabbage heads (Pederson et al., 1962; Cvetković et al., 2013; Cvetković et al., 2015; Beganović et al., 2014). The main goal of this study wasto monitor changes of bioactive compounds from raw cabbage head to the biologically fermented product obtained on different temperature intervals. The brine which belongs to each sample was also taken for the purpose of the analysis. Dry weight, soluble dry weight, $\mathrm{pH}$ value, water activity, salt concentration, total sugar concentration, total acidity, penetration force, total color change, total phenolic compounds and organic acids are investigated as the most suitable quality indicators of the cabbage fermentation. 


\section{MATERIAL AND METHOD}

\section{Sample}

Cabbage heads (Brassica oleracea var. capitata) were harvested from a field in Futog (Vojvodina, Serbia). Fresh cabbage hybrid bravo was picked in September and used for the purpose of analysis. Three fermented cabbage samples, with corresponding brine samples, were taken from the places with three different temperatures after 40 days of fermentation process. After finished fermentation cabbage samples were shredded to pulp and, together with brine samples, frozen and stored at $-20{ }^{\circ} \mathrm{C}$ prior to analysis in order to prevent potential deteriorative processes in the samples.

Chemicals

Folin-Ciocalteu reagent was purchased from Sigma ("SigmaAldrich" GmbH, Steinheim, Germany). Orto-phosphoric acid was purchased from "Kemika" Zagreb, acetic acid standard from J.T. Baker (Holland), formic acid standard from "Sigma Aldrich", Steinheim, lactic and oxalic acid standards from Laborat. Laphoma Hemikalifrom Skopje and succinic acid standard from "Supelco Analytical", Bellefonte. All other chemicals and reagents were of analytical reagent grade.

Fermentation procedure

Cabbage hybrid bravo has been subjected to spontaneous fermentation process in "Agricultural holding Predrag Kurjakov", Futog. Primarily, fresh raw cabbage heads were selected in order to discard diseased and injuries. Afterwards, leaves on the top of each head were removed to reduce impurities and some undesirable extraneous microorganisms. Cabbage cores were notched in the shape of a crossin order to facilitate salt diffusion into the cabbage heads.

After the preparation of raw material, twowhole cabbage headswere stacked in the plastic vats and the third one in the pool. In both vats and pool, $6 \% \mathrm{NaCl}$ water solution was added. Temperature intervals in pool and vats were $16-18{ }^{\circ} \mathrm{C}, 18-20{ }^{\circ} \mathrm{C}$ and $20-22{ }^{\circ} \mathrm{C}$, respectively. The vat, which was held at temperature $18-20{ }^{\circ} \mathrm{C}$ was located in the basement.All three spontaneous fermentation processes lasted for 40 days.

Analyses

Dry weight

Dry weightwas determined by drying approximately $2 \mathrm{~g}$ of samples at $105{ }^{\circ} \mathrm{C}$ until reaching the constant weight. The samples were mixed with quartz sand in order to increase surface evaporation and shorten the drying time. Experiments were performed in three replicates and expressed as percentage (\%).

Soluble dry weight

Soluble dry weight content was read from the universal Abberefractometer scale after placing the samples. Experiments were performed in three replicate and expressed as percentage (\%).

\section{$\mathrm{pH}$ value}

Results were obtained by immersing the $\mathrm{pH}$ electrode in the cabbage pulp and brine samples and reading the values on WTW Inolab $720 \mathrm{pH}$-meter (Netherlands), at $25{ }^{\circ} \mathrm{C}$. $\mathrm{pH}$ values were recorded after equilibration.

Water activity

Water activity was determined by placing approximately $3 \mathrm{~g}$ of cabbage pulp or brine in the sample holder of a LabSwifta ${ }_{\mathrm{w}}^{-}$ meter "Novasina" (Switzerland) at $25{ }^{\circ} \mathrm{C} . \mathrm{a}_{\mathrm{w}}$ values were recorded after equilibration.

Salt concentration

The salt concentration in the samples were determined by method according to Mohr (Kolarov at al., 1996). Analyzes have been conducted in two replicates and results were expressed as percentage (\%).
Total sugar concentration

In the order to track changes of sugar concentration from raw to fermented cabbage, samples were analyzed following the Luff-Schoorl method (Vračar, 2001). The chemical analyzes have been conducted twice and results were expressed as percentage (\%).

Total acidity

Total acidityof cabbage pulp and brine samples, expressed as lactic acid, was measured by titration using $0.1 \mathrm{M} \mathrm{NaOH}$ with phenolphthalein as indicator (Vračar, 2001).All chemical analyzeshave been conductedtwice and results were expressed as percentage (\%).

Penetration force

Measurements were carried out immediately after samples were defrosted. For the purpose of these experiments whole cabbage leaves were used as the samples. Instrumental texture measurements were performed using a Texture Analyzer (TE32, Stable Micro Systems, UK) by using penetration-force test. The penetration test was carried using $2 \mathrm{~mm}$ stainless Cylinder probes and Heavy Duty Platform. TA settings - $2.0 \mathrm{~mm} / \mathrm{s}$; distance $-20 \mathrm{~mm}$; load cell $-5 \mathrm{~kg}$ were set for penetration force analysis. Penetration force has been expressed as force (g) required for penetration through the samples.

Total color change

Total color change $(\Delta \mathrm{E})$ measuringwascarried out immediately after samples were defrosted and whole cabbage leaves were used as the samples. The CIE $\mathrm{L}^{*} \mathrm{a}^{*} \mathrm{~b}{ }^{*}$ color coordinates were measured by using Chroma Meter CR-400 (Minolta Co., Ltd., Osaka, Japan). The surface color of all cabbage leaves samples was measured in terms of $L$ (degree of darkness), $a$ (degree of redness and greenness) and $b$ (degree of yellowness and blueness). Total color change between raw cabbage sample $\left(\mathrm{L}_{0}{ }^{*}, \mathrm{a}_{0}{ }^{*}\right.$ and $\left.\mathrm{b}_{0}{ }^{*}\right)$ and fermented cabbage samples $\left(\mathrm{L}^{*}, \mathrm{a}^{*}\right.$ and $\left.\mathrm{b}^{*}\right)$ was determined according to Equation (1):

$$
\Delta E=\sqrt{\left[\left(L_{0} *-L *\right)^{2}+\left(a_{0} *-a *\right)^{2}+\left(b_{0} *-b *\right)^{2}\right]}
$$

Measure head of Chroma Meter was placed on each sample and measurements of color were performed for all prepared samples. A standard white color was used for calibration and experiments were replicated seven times for statistical purpose.

Total phenolics content

Cabbage pulp samples were defrosted prior extraction. Approximately $10 \mathrm{~g}$ of pulp sample was transferred to volumetric flask and $50 \mathrm{~mL}$ of methanol was added as extraction solvent. Extraction was carried out for $24 \mathrm{~h}$ at the roomtemperature for each pulp sample. The obtained extracts and brine samples (after defrosting) were filtered, placed into a glass bottles and stored to prevent oxidative damage until analysis. The content of total phenolic compounds in methanolic extracts and brine filtrateswas determined by Folin-Ciocalteu procedure (Singleton and Rossi, 1965; Kähkönen et al., 1999) using chlorogenic acid as a standard. Absorbance was measured at $765 \mathrm{~nm}$ (6300 Spectrophotometer, Jenway, UK). The content of total phenolic compounds has been expressed as $\mathrm{mg}$ of chlorogenic acid equivalents per $100 \mathrm{~g}$ of dry weight for cabbage samples and as mg of chlorogenic acid equivalents per $100 \mathrm{~mL}$ for brine samples (mg CAE/100 g DW and mg CAE/100 mL, respectively). Experiments were replicated two times and results are expressed as mean values.

Organic acids content

Approximately $20 \mathrm{~g}$ of each cabbage sample was shredded into pulp with bidistilled water in the ratio 1:1.75. The pulps were homogenized by using ultraturrax Heidolph Diax900 ("Gemini BV", Nederland) and magnetic stirrer MSH-420 
("Boeco", Germany) and then centrifuged ("Janetzki", Deutschland) at $4000 \mathrm{rpm}$. The supernatants were used for further analysis. The brine samples were filtered through a filter paper prior analysis. Determination of organic acids in cabbage pulp and brine samples was performed using the reversed phase HPLC, with Agilent 1100 Series HPLC (USA) according to Kordiš-Krapežet al. (2001) withslight modifications in terms of column type, detection wavelength and column temperature. System was equipped with degasser, binary pump, ZORBAX ${ }^{\circledR}$ SB-C18 column (4.6x150 mm, 5-Micron) and UV-DAD detector. Analysis was performed in isocratic mode with 6 $\mathrm{mmol} / \mathrm{L}$ phosphoric acid $(\mathrm{pH} 2.1)$ as a mobile phase. LC parameters were set as follows: flow rate $1.0 \mathrm{~mL} / \mathrm{min}$, column temperature $28{ }^{\circ} \mathrm{C}$, detection wavelength for oxalic, formic, lactic, acetic and succinic acid was $220 \mathrm{~nm}$. Organic acids standards were used for external standard method of calibration.Results were expressed as mg/100 g DW and mg/mL for cabbage samples and brine samples, respectively.Allanalyses were done in duplicate.

\section{RESULTS AND DISCUSSION}

Seven samples (one raw and three fermented cabbages andthree brine samples) were used for experiments. The alterations from raw to fermented cabbage at differenttemperature intervals was observed by monitoringofphysico-chemical properties. Physico-chemical parameters followed in this study were: dry weight (DW), soluble dry weight $(\mathrm{SDW}), \mathrm{pH}$ value $(\mathrm{pH})$, water activity $\left(\mathrm{a}_{\mathrm{w}}\right)$, salt concentration $(\mathrm{NaCl})$, total sugar concentration (TSC), total acidity (TAC), penetration force $(\mathrm{PF})$, total color changes $(\triangle \mathrm{E})$, total phenolic content(TPC)and organic acids contents. Experimentally obtained values of DW, SDW, $\mathrm{pH}, \mathrm{a}_{\mathrm{w}}, \mathrm{NaCl}$, TSC and TACof raw cabbagesample $\left(\mathrm{C}_{0}\right)$, cabbage samples fermented at the temperature intervals $16-18{ }^{\circ} \mathrm{C}\left(\mathrm{C}_{1}\right), 18-20{ }^{\circ} \mathrm{C}$ $\left(\mathrm{C}_{2}\right)$ and $20-22{ }^{\circ} \mathrm{C}\left(\mathrm{C}_{3}\right)$ and corresponding brine samples $\left(\mathrm{B}_{1}, \mathrm{~B}_{2}\right.$, $\mathrm{B}_{3}$ ) are presented in Table (1). Presented results are the average of the obtained values.Number of repetitions are presented in chapter Material and Method for each analyzeseparately.

Table 1. Experimentally obtained values of dry weight, soluble dry weight, $p H$ value, water activity, salt concentration, total sugar concentration and total acidityof raw and fermented cabbage and brine samples

\begin{tabular}{|c|c|c|c|c|c|c|c|}
\hline Sample & $\begin{array}{l}\text { DW } \\
(\%)\end{array}$ & $\begin{array}{c}\text { SDW } \\
(\%)\end{array}$ & $\overline{\mathrm{pH}}$ & $a_{w}$ & $\begin{array}{c}\mathrm{NaCl} \\
(\%)\end{array}$ & $\begin{array}{l}\text { TSC } \\
(\%)\end{array}$ & $\begin{array}{l}\text { TAC } \\
\text { (\%) } \\
\end{array}$ \\
\hline $\mathrm{C}_{0}$ & 9.45 & 5.97 & 5.90 & 0.997 & 0.05 & 3.91 & 0.15 \\
\hline $\mathrm{C}_{1}$ & 7.88 & 6.00 & 3.49 & 0.981 & 0.79 & 1.70 & 0.69 \\
\hline $\mathrm{C}_{2}$ & 7.69 & 6.00 & 3.12 & 0.976 & 2.19 & 0.58 & 0.79 \\
\hline $\mathrm{C}_{3}$ & 7.97 & 7.00 & 2.97 & 0.967 & 2.45 & 0.27 & 0.75 \\
\hline $\mathrm{B}_{1}$ & 4.64 & 4.63 & 3.00 & 0.972 & 2.84 & nd* & 0.67 \\
\hline $\mathrm{B}_{2}$ & 5.26 & 5.00 & 3.16 & 0.972 & 3.18 & nd* & 0.23 \\
\hline $\mathrm{B}_{3}$ & 5.95 & 4.90 & 3.08 & 0.974 & 3.27 & nd* & 0.39 \\
\hline
\end{tabular}

\section{Physico-chemical properties}

Dry weight (DW) dependsongrowing conditions and cultivation manner of a cabbage and it is a very important indicator of a raw and fermented cabbage quality and maturity. Late fall cabbage varieties and hybrids have higher DW and give fermented cabbage with higher quality compared to early cultivars (Červenski, 2010). DW in raw cabbage was $9.45 \%$ which is similar withthe results of Mirecki (2001) where it is reported that DW is in the range of $9.21 \%$ and $10.46 \%$.In all cabbage samples DW was between $7.69 \%$ and $7.97 \%$ which indicates that the temperature of fermentation did not influence DW significantly during the fermentation. The range of DW in brine samples varied between $4.64 \%$ and $5.95 \%$. It was noticed that DW of brine samples increase with the increasing of fermentation temperature.

Soluble dry weight (SDW) of fresh cabbage is consisted of water-soluble compounds such as sugars, acids, etc. More than 3 $\%$ of these compounds content is generally required for a successful fermentation (Dobričević and Pliestić, 2004). Soluble dry weight of the raw cabbage was $5.97 \%$. As in the case of DW, in both cabbage and brine samples there were no significant differences between SDW of cabbage samples. Also, the range of SDW observed for cabbage samples was higher than the range of SDW obtained for brine samples.

Lactic-acid bacteria produces lactic acid until all sugars are consumed,thus $\mathrm{pH}$ during the fermentation usually drops from 6.0 to 3.4 (Bamfort, 2005). Reducing $\mathrm{pH}$ value during the fermentation process inhibits the formation of lactic acid (Hui and Evranuz, 2012; National Research Council, 1992). Given that, $\mathrm{pH}$ value presents a very good indicator of the process of cabbage fermentation. $\mathrm{pH}$ value of the raw sample was 5.90, whilepH values of cabbage samples varied between 2.97 and 3.49. It could be seen that $\mathrm{pH}$ values obtained for cabbage samples $(2.97,3.12,3.49)$ increased with the reduction oftemperature intervals $\left(20-22{ }^{\circ} \mathrm{C}, 18-20{ }^{\circ} \mathrm{C}, 16-18{ }^{\circ} \mathrm{C}\right)$. However, there was no significant difference in $\mathrm{pH}$ values obtained from brine samples, so it could be concluded that the temperature did not influence significantly on $\mathrm{pH}$ of brine samples during fermentation.

Water activity $\left(a_{w}\right)$ is used for predicting the subsistence and growth of microorganisms in food and it directly influences the product quality and stability (Barbosa-Cánovas et al., 2007). Microorganisms generally grow best between $\mathrm{a}_{\mathrm{w}}$ values 0.995 0.980 (Gibbs and Gekas, 1998). $\mathrm{a}_{\mathrm{w}}$ value ofraw cabbage sample was 0.997 . It could be seen that in the case of cabbage samples $\mathrm{a}_{\mathrm{w}}$ values decrease with the increasing of fermentationtemperature. $a_{\mathrm{w}}$ values obtainedfrom brine samples did not show any significant influence of the fermentation temperature. The highest $\mathrm{a}_{\mathrm{w}}$ value of all samples was obtained in $\mathrm{C}_{1}$, on the lowesttemperature used for investigation $\left(16-18{ }^{\circ} \mathrm{C}\right)$.

$\mathrm{NaCl}$ is the main promoter of the lactic-acid bacteria producing and growing during afermentation process. Based on this, it also presents a good indicator of the fermentation process quality.NaCl addition stimulates the secretion of the cabbage cell juice due to osmotic difference of salt content in water and in cabbage. This also causes a reduction of $\mathrm{a}_{\mathrm{w}}$ value. $\mathrm{NaCl}$ in the raw cabbage was $0.05 \%$.For cabbage fermentation, Tuzlanska salt (Solana d.d. Tuzla, Bosnia and Herzegovina) was used. NaClcontent in $\mathrm{C}_{1}, \mathrm{C}_{2}$ and $\mathrm{C}_{3}$ was $0.79 \%, 2.19 \%$ and $2.45 \%$, respectively and it increased with increase of fermentation temperature $16-18{ }^{\circ} \mathrm{C}, 18-20^{\circ} \mathrm{C}, 20-22{ }^{\circ} \mathrm{C}$, respectively. It was noticed that the highest content of $\mathrm{NaCl}$ in cabbage samples was obtained in $C_{3}$, where was also obtained the lowest $a_{w}$ value of all cabbage samples. These could be expected since these two parameters are in direct correlation. $\mathrm{NaCl}$ contents in all brine samples were in the range from $2.84 \%$ to $3.27 \%$ which is higher compared to the range of $\mathrm{NaCl}$ content obtained in cabbage samples. These results could be expected, since $\mathrm{NaCl}(6 \%)$ was added in water solution for fermentation and thus most of this amount was retained in brine. The highest $\mathrm{NaCl}$ content of all brine samples was obtained in $\mathrm{B}_{3}$, e.t. on the highest temperature used for investigation $\left(20-22{ }^{\circ} \mathrm{C}\right)$. 
Sugar is being converted into lactic acid during fermentation process and so the initialtotal sugar content (TSC) in raw cabbage is very important indicator for cabbage fermentation. Optimal content of sugar for fermentation varied between $3.5 \%$ and $6.5 \%$ and it should not be less than $3 \%$ (Niketić-Aleksić, 1988; Červenski, 2010). TSC of the raw cabbage was $3.91 \%$ and it could be seen that in terms of sugar content, the cabbage used for fermentation was suitable for fermentation. In fermented cabbage samples $\mathrm{C}_{2}$ and $\mathrm{C}_{3}$ were obtained very low TSC ( $0.58 \%$ and $0.27 \%$, respectively) which indicates that 40 days of fermentation was enough for a satisfactory fermentation of these two samples. However, TSC obtained in $\mathrm{C}_{1}$ was quite higher and it could be concluded that combination of the temperature $\left(16-18{ }^{\circ} \mathrm{C}\right)$ and duration of the fermentation $(40$ days) influenced less good than the other fermentation combinations in terms of TSC in fermented samples. As it was expected, TSC in brine samples were not detected.

Total acids content of the raw cabbage sample was $0.15 \%$ which fits well with the literature data obtained in Vračar (2001) where titratable acidity in raw cabbage varied between $0.1 \%$ and $0.4 \%$. However, results obtained for total acids content (TAC) are expressed on the lactic-acid considering that it is dominant acid in biologically fermented products. TAC in cabbage samples varied between $0.69 \%$ and $0.79 \%$ while this range for brine samples was quite lower and between $0.23 \%$ and $0.67 \%$.

A lot of factors influence the texture of cabbage leaves during fermentation process. $\mathrm{NaCl}$ addition influences positively on the cabbage leaves texture, since it prevents the softening of the tissue. The softening of cabbage leaves can also be caused bybacteria such as Enterobacter,Flavobacterium, andPseudomonas when the fermentation temperature is lower than $10^{\circ} \mathrm{C}$ and when the content of added $\mathrm{NaCl}$ is lower than 2 $\%$ (Hutkins, 2006). Since the investigated fermentation temperature intervals were between $16{ }^{\circ} \mathrm{C}$ and $22{ }^{\circ} \mathrm{C}$ and $\mathrm{NaCl}$ was added more than $2 \%$ it was noticed that there was no significant difference in texture between fermented and raw cabbage leaves. Penetration force (PF) of raw cabbage leaves was $315 \mathrm{~g}$, while the PF of fermented cabbage leaves varied between 307 and $418 \mathrm{~g}$. The lowest PF was obtained in $\mathrm{C}_{3}(20-$ $22{ }^{\circ} \mathrm{C}$ ) while the highest was obtained in $\mathrm{C}_{2}\left(18-20^{\circ} \mathrm{C}\right)$. These results indicates that temperatures used for the cabbage fermentation did not cause softening of cabbage products and that there was no significant difference between investigated cabbage samples.

Along with the texture, color is the main characteristic that makesa product appealingto consumers.Significant changes in color are usually occurredwith the less good fermentation process. Brown color of cabbage usually occurs due to oxidation of phenolic compounds. Red, pink and gray colors may appear on cabbage during fermentation due to the metabolism of undesirable microorganisms (Niketić-Aleksić, 1988; Červenski, 2010). The obtained total color change (TCC) of cabbage samples varied between 10.32 and 12.14. These results did not present significantly high difference since it is assumed that the $\Delta \mathrm{E}$ less than 1 is not sensory notable (Filimon et al., 2011). The highest TCC was obtained in $\mathrm{C}_{3}$ which could be explained with the influence of the highest investigated temperature used for the cabbage fermentation.

Phenolic compounds belong to the group of biologically active substances important for human health due to antimicrobial, antiviral and anti-inflammatory properties (Ignat et al., 2011).Cabbage is known as a source of compounds with significant antioxidant activity since it is rich in polyphenolic compounds located in cabbage cells as a free molecule or in bond form (Shahidi and Priyatharini, 2015). Total phenol content and antioxidant activities increases during the fermentation process since Lactobacillus plantarumand Lactobacillus brevis are capable to release bonded phenolic compounds during fermentation. Additionally, proteolytic enzymes from fermentable microorganisms hydrolyze phenolic compounds into more biologically active forms (Acosta-Estrada et al., 2014). Cabbage samples showed significantly higher total phenol content (TPC) in comparison withthe raw cabbage sample (Graph 1). It was noted that the lower fermentation temperature influenced on higher TPC in cabbage samples. However, TPC in $\mathrm{C}_{1}, \mathrm{C}_{2}$ and $\mathrm{C}_{3}$ were $240.1 \%, 197.3 \%$ and $171.1 \%$ higher compared to the raw cabbage sample, respectively. TPC obtained in brine samples (Graph 2) varied between 4.75 and $8.35 \mathrm{mg}$ CAE/100 mL. The highest TPC in brine samples was obtained in $\mathrm{B}_{1}\left(16-18{ }^{\circ} \mathrm{C}\right)$ while the lowest TPC inbrine samples was obtained in $\mathrm{B}_{2}\left(18-20^{\circ} \mathrm{C}\right)$. On the basis oftheseresults it could be seen that the highest content of TPC was obtained on the lowest fermentation temperature, as it was the case with cabbage samples.

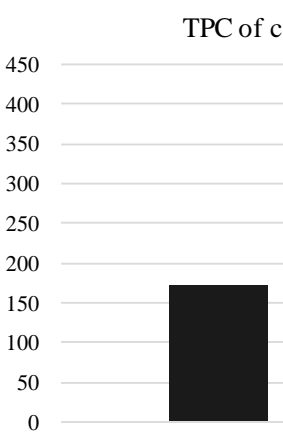

$\mathrm{C} 0$

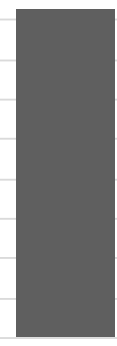

C1

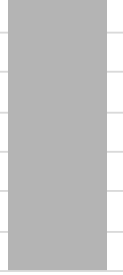

C2

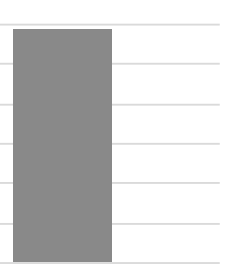

C3
Figure 1. Total phenolic content in raw and fermented cabbage samples

Number of repetitions are presented in chapter Material and Method

TPC of brine $[\mathrm{mg} \mathrm{CAE} / 100 \mathrm{~mL}]$

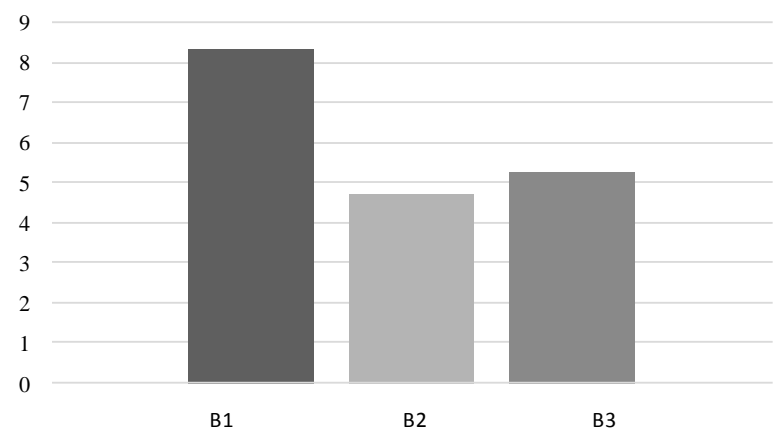

Figure 2. Total phenolic content in brine samples Number of repetitions are presented in chapter Material and Method

Short chain organic acids possess antimicrobial activity and sometimes they are also used as disinfectants forfresh fruits and vegetables (Huang and Chen, 2011). Some of them, includingoxalic acid, arenaturally present in the raw cabbage (Sinha, 2011).Oxalic acid has positive effects on cabbage properties during the storage before processing, since it increases the antioxidant capacity and inhibits the degradation of raw material (Wang et al., 2016). During the fermentation process, the changein the $\mathrm{pH}$ and oxygen concentration levels led to 
formation of other organic acids such as lactic, acetic, formic and succinic acid (Farnworth, 2008). Sugar biotransformation causes formation of lactic acid which gives a sharp taste to a fermented cabbage and also compounds such as acetic acid, ethanol and $\mathrm{CO}_{2}$ (Sinha, 2011). Acetic and formic acids possess higher inhibitory properties compared to lactic acid and these acids also increase protective effects of the desirable lactic-acid bacteria (Marthand Steele, 2001). Obtained oxalic acid content in the raw cabbage sample was $4716.6 \mathrm{mg} / 100 \mathrm{~g}$ DW and it was noticed that the content of oxalic acid in cabbage samples decreased during the fermentation. The higher temperatures caused lower oxalic acids contents in $\mathrm{C}_{1}, \mathrm{C}_{2}$ and $\mathrm{C}_{3}$ samples (4200.9 mg/100 g DW, 3082.7 mg/100 g DW,and 1123.3 $\mathrm{mg} / 100 \mathrm{~g}$ DW, respectively). Lactic, acetic, formic and succinic acids were not detected in raw cabbage samples. With the increase of temperature during fermentation, the lactic acid contents in $\mathrm{C}_{1}, \mathrm{C}_{2}$ and $\mathrm{C}_{3}$ samples (3069.4 mg/100 g DW, 4581.9 $\mathrm{mg} / 100 \mathrm{~g}$ DW, $5201.0 \mathrm{mg} / 100 \mathrm{~g} \mathrm{DW}$, respectively) also increased. As in the case of oxalic acid, the contents of acetic acid in $\mathrm{C}_{1}, \mathrm{C}_{2}$ and $\mathrm{C}_{3}$ samples (4134.3 mg/100 g DW, 2342.8 $\mathrm{mg} / 100 \mathrm{~g}$ DW to $1767.4 \mathrm{mg} / 100 \mathrm{~g} \mathrm{DW}$, respectively) also decreased. Formic acid was detected only in $\mathrm{C}_{3}$ sample (1334.1 $\mathrm{mg} / 100 \mathrm{~g}$ DW)on the higher fermentation temperature $20-22^{\circ} \mathrm{C}$. Organic acids contents obtained for cabbage and brine samples are presented in Table 2. Succinic acid was detected in all cabbage and brine samples but it was no quantified.

Table 2. Experimentally obtained values of organic acids contents offermented cabbage and brine samples

\begin{tabular}{|c|c|c|c|c||}
\hline Sample & Oxalic acid & Lactic acid & Acetic acid & Formic acid \\
\hline $\mathrm{C}_{1}{ }^{1}$ & 4200.9 & 3069.4 & 4134.3 & $/$ \\
\hline $\mathrm{C}_{2}{ }^{1}$ & 3082.7 & 4581.9 & 2342.8 & $/$ \\
\hline $\mathrm{C}_{3}{ }^{1}$ & 1123.3 & 5201.0 & 1767.4 & 1334.1 \\
\hline $\mathrm{B}_{1}{ }^{2}$ & 1.16 & 2.53 & 0.86 & $/$ \\
\hline $\mathrm{B}_{2}{ }^{2}$ & 0.46 & 0.91 & 0.31 & $/$ \\
\hline $\mathrm{B}_{3}{ }^{2}$ & 0.19 & 2.17 & 1.01 & 0.69 \\
\hline
\end{tabular}

As it was the case with cabbage samples, oxalic acid contents ofB $B_{1}, B_{2}$ and $B_{3}$ samples $(1.16 \mathrm{mg} / \mathrm{mL}, 0.46 \mathrm{mg} / \mathrm{mL}$, and $0.187 \mathrm{mg} / \mathrm{mL}$, respectively) decreasedwith an increase ofthe temperature of the fermentation. Lactic and acetic acid contentsof the brine samples varied between $0.91 \mathrm{mg} / \mathrm{mL}$ and $2.53 \mathrm{mg} / \mathrm{mL}$ and between $0.31 \mathrm{mg} / \mathrm{mL}$ and $1.01 \mathrm{mg} / \mathrm{mL}$, respectively. In the case of brine samples, higher value of lactic acid was obtained in $\mathrm{B}_{1}\left(16-18{ }^{\circ} \mathrm{C}\right)$ and also for acetic acid $\mathrm{B}_{3}\left(20-22^{\circ} \mathrm{C}\right)$ which is opposite compared to $\mathrm{C}_{1}$ and $\mathrm{C}_{3}$ samples. As in the case of cabbage samples, formic acid was detected only in $\mathrm{B}_{3}\left(20-22{ }^{\circ} \mathrm{C}\right)$.

\section{CONCLUSIONS}

On the basis of the obtained resultsit could beinferred that the highest content of total phenol compounds in cabbage and brine samples(414.71 mg CAE/100g DW and $8.35 \mathrm{mg}$ CAE/100 $\mathrm{mL}$, respectively), the highest contents of oxalic and acetic acid in cabbage samples (4200.9 mg/100g DW and $4134.3 \mathrm{mg} / 100 \mathrm{~g}$ DW, respectively) and the highest contents of oxalic and lactic acid in brine samples $(1.16 \mathrm{mg} / \mathrm{mL}$ and $2.53 \mathrm{mg} / \mathrm{mL})$ were obtained in samples fermented at the lowest investigated temperature interval $\left(16-18{ }^{\circ} \mathrm{C}\right)$. The highest content of lactic acid in cabbage samples (5201.0 mg/100g DW) and the highest content of acetic acid in brine samples $(1.01 \mathrm{mg} / \mathrm{mL})$ were observed in samples fermented at the highest investigated temperature interval $\left(20-22{ }^{\circ} \mathrm{C}\right)$. Formic acid in cabbage and brine samples (1334.1 mg/100 g DW and0.69 mg/mL) was detected only in samples fermented at the highest fermentation temperatureinterval $\left(20-22{ }^{\circ} \mathrm{C}\right)$.

\section{ACKNOWLEDGMENTS}

The research is part of the project entitled"Development of technology for drying of fermented juice from Futog cabbage with main aim production of new functional products in form of tablet of powder" (Project No.114-451-2526/2016) and is financially supported by the Provincial Secretariat for Agriculture, Water Management and Forestry, Autonomous Province of Vojvodina, Republic of Serbia.

The authors would like to thank PredragKurjakov for cooperation in performing the fermentation process in “Agricultural holding Predrag Kurjakov”, Futog.

\section{REFERENCES}

Acosta-Estrada, B. A., Gutiérrez-Uribe, J. A., Serna-Saldívar, S. O. (2014). Bound phenolics in food, a review. Food Chemistry, 152, 46-55.

Bamfort, C. W. (2005). Food, Fermentation and Microorganisms. Blackwell, Oxford, UK.

Barbosa-Cánovas, G. V., Fontana, J. A., Schmidt, S. J., Labuza, T. P. (2007). Water activity in foods: fundamentals and applications (Vol. 13). Blackwell, Iowa, USA.

Batt, C. A. (2016). Microbiology of Fermentations. Reference Module in Food Science. Elsevier, Ithaca, NY, USA.

Beganović, J., Kos, B., Pavunc, A. L., Uroić, K., Jokić, M., Sušković, J. (2014). Traditionally produced sauerkraut as source of autochthonous functional starter cultures. Microbiological research, 169(7), 623-632.

Cvetković, B. (2014). Primena tehnoloških postupaka spontane fermentaciji i osmotske dehidratacije za unapređenje nutritivnog profila, senzornih svojstava i održivosti kupusa. Doktorska disertacija. Tehnološki fakultet, Novi Sad: Srbija.

Cvetković, B. R., Pezo, L. L., Tasić, T., Šarić, L., Kevrešan, Ž., Mastilović, J. (2015). The optimisation of traditional fermentation process of white cabbage (in relation to biogenic amines and polyamines content and microbiological profile). Food chemistry, 168, 471-477.

Cvetković, B., Jokić, A., Lević, L., Kevrešan, Ž. (2013). Osmotic dehydration of white cabbage in different hypertonic solutions: Mass transfer kinetics and improvement of nutritional value of the developed product. Journal on Processing and Energy in Agriculture, 17(4), 154-157.

Červenski, J. (2010). Gajenje kupusa. Institut za ratarstvo i povrtarstvo, Novi Sad, Srbija.

Dobričević, N., Pliestić, S. (2004). Quality of Cabbage Cultivars Intended for Fermentation in the Ogulin Region. Agriculturae Conspectus Scientificus, 69, 109-113.

Farnworth, E. R. (2008). Handbook of Fermented Functional Foods, Second Edition. Taylor \& Francis Group, Boca Raton, Florida.

Filimon, R., Niculaua, M., Sârbu, S., Filimon, R., Arion, C. (2011). Determination of chromatic characteristics of the hydroalcoholic extracts obtained from the fruits of some cherry and sour cherry varieties. Lucrăriştiinţifice, seria Agronomie, 54(1), 124-129.

Gänzle, M. G. (2015). Lactic metabolism revisited: metabolism of lactic acid bacteria in food fermentations and food spoilage. Food Science, 2, 106-117. 
Gibbs, P., Gekas, V. (1998). Water activity and microbiological aspects of foods. A knowledge base. Leatherhead Food Research Association, Leatherhead, UK.

Harbaum-Piayda, B., Palani, K., Schwarz, K. (2016). Influence of postharvest UV-B treatment and fermentation on secondary plant compounds in white cabbage leaves. Food Chemistry, 197, 47-56.

Huang, Y., Chen, H. (2011). Effect of organic acids, hydrogen peroxide and mild heat on inactivation of Escherichia coli E157:H7 on baby spinach. Food Control, 22, 1178-1183.

Hui, Y. H., \& Evranuz, E. Ö. (2012). Handbook of Plant-based fermented food and beverage technology. CRC Press.

Hutkins, R. W. (2006). Microbiology and Technology of Fermented Foods. Wiley-Blackwell, Iowa, USA.

Ignat, I., Volf, I., Popa, V. (2011). A critical review of methods for characterisation of polyphenolic compounds in fruits and vegetables. Food Chemistry, 126(4), 1821-1835.

Jevšnik, M., Hlebec, V., Raspor, P. (2009). Survey of safe and hygienic practices among Slovenian sauerkraut growers. Food Control, 20, 677-685.

Kähkönen, M. P., Hopia, A. I., Vuorela, H. J., Rauha, J. P., Pihlaja, K., Kujala, T. S.,Heinonen, M. (1999). Antioxidant activity of plant extracts containing phenolic compounds.Journal of agricultural and food chemistry, 47(10), 3954-3962.

Kolarov, Lj., A., Lončar, E., S., Ačanski, M., M. (1996). Kvantitativna hemijska analiza, praktikum sa elementima teorije. Tehnološki fakultet, Novi Sad, Srbija.

Kordiš-Krapež, M., Abram, V., Kač, M., Ferjančić, S. (2001). Determination of organic acids in white wines by RP-HPLC. Food Technology and Biotechnology, 39(2), 93-99.

Kumar, R., Pranay, J. (2010). Change in Microflora of Sauerkraut During Fermentation and Storage. World Journal of Dairy \& Food Science, 5(2), 221-225.
Marth, E. H., Steele, J. L. (2001). Applied Dairy Microbiology, Second Edition, Revised and Expanded. Marcel Dekker, New York, USA.

Mirecki, N. (2001). Uticaj sorte i vremena sadnje na kvalitet kupusa. Savremena poljoprivreda, 50, 117-122.

National Research Council. Applications of biotechnology in traditional fermented foods. National Academies Press, 1992.

Niketić-Aleksić, G. (1988). Tehnologija voća i povrća. Poljoprivredni fakultet, Beograd, Srbija.

Pederson, C. S., Niketić, G., Albury, M. N. (1962). Fermentation of the Yugoslavian Pickled Cabbage. Applied microbiology, 10, 86-89.

Shahidi, F., Priyatharini, A. (2015). Phenolic and polyphenolic in foods beverages and spices: Antioxidant activity and health effects-A review. Journal of Functional Foods, 18, 820-897.

Singleton, V. L., Rossi, J. A. (1965).Colorimetry of total phenolics with phosphomolybdic-phosphotungstic acid reagents. American journal of Enology and Viticulture, 16(3), 144-158.

Sinha, N. K. (2011). Handbook of Vegetables and Vegetable Processing. Wiley-Blackwell, Iowa, USA.

Terefe, N. S. (2016). Food Fermentation. Reference Module in Food Science. Elsevier, Werribee, Australia.

Vračar, Lj. O. (2001). Priručnik za kontrolu kvaliteta svežeg i prerađenog voća, povrća i pečurki i osvežavajućih bezalkoholnih pića. Tehnološki fakultet, Novi Sad, Srbija.

Wang, Z., Cao, J., Jiang, W. (2016). Changes in sugar metabolism caused by exogenous oxalic acid related to chilling tolerance of apricot fruit. Postharvest Biology and Technology, 114, 10-16.

Received: 31. 03. 2017.

Accepted: 01. 09. 2017. 